\title{
Paricalcitol Inhibits Aldosterone-Induced Proinflammatory Factors by Modulating Epidermal Growth Factor Receptor Pathway in Cultured Tubular Epithelial Cells
}

\author{
Jose L. Morgado-Pascual, ${ }^{1,2}$ Sandra Rayego-Mateos, ${ }^{1,2}$ Jose M. Valdivielso, ${ }^{2,3}$ \\ Alberto Ortiz, ${ }^{2,4,5}$ Jesus Egido, ${ }^{5,6,7}$ and Marta Ruiz-Ortega ${ }^{1,2}$ \\ ${ }^{1}$ Cellular Biology in Renal Diseases Laboratory, IIS-Fundación Jimenez Diaz, Universidad Autónoma Madrid (UAM), \\ 28040 Madrid, Spain \\ ${ }^{2}$ REDINREN, Madrid, Spain \\ ${ }^{3}$ Department of Experimental Nephrology, Universitat de Lleida/Institut de Recerca Biomèdica de Lleida, 25198 Lleida, Spain \\ ${ }^{4}$ Dialysis Unit, IIS-Fundación Jiménez Díaz, School of Medicine, UAM, Madrid, Spain \\ ${ }^{5}$ Institute of Renal Research Queen Sophia (IRSIN), Spain \\ ${ }^{6}$ Division of Nephrology and Hypertension, IIS-Fundación Jiménez Díaz, UAM, Madrid, Spain \\ ${ }^{7}$ Spanish Biomedical Research Centre in Diabetes and Associated Metabolic Disorders (CIBERDEM), Spain \\ Correspondence should be addressed to Marta Ruiz-Ortega; mruizo@fjd.es
}

Received 31 October 2014; Accepted 11 January 2015

Academic Editor: Luca De Nicola

Copyright (C) 2015 Jose L. Morgado-Pascual et al. This is an open access article distributed under the Creative Commons Attribution License, which permits unrestricted use, distribution, and reproduction in any medium, provided the original work is properly cited.

Chronic kidney disease is characterized by Vitamin D deficiency and activation of the renin-angiotensin-aldosterone system. Increasing data show that vitamin D receptor agonists (VDRAs) exert beneficial effects in renal disease and possess antiinflammatory properties, but the underlying mechanism remains unknown. Emerging evidence suggests that "a disintegrin and metalloproteinase" (ADAM)/epidermal growth factor receptor (EGFR) signalling axis contributes to renal damage. Aldosterone induces EGFR transactivation regulating several processes including cell proliferation and fibrosis. However, data on tubular epithelial cells is scarce. We have found that, in cultured tubular epithelial cells, aldosterone induced EGFR transactivation via TGF$\alpha /$ ADAM17. Blockade of the TGF- $\alpha$ /ADAM17/EGFR pathway inhibited aldosterone-induced proinflammatory gene upregulation. Moreover, among the potential downstream mechanisms, we found that TGF- $\alpha$ /ADAM17/EGFR inhibition blocked ERK and STAT-1 activation in response to aldosterone. Next, we investigated the involvement of TGF- $\alpha$ /ADAM17/EGFR axis in VDRA anti-inflammatory effects. Preincubation with the VDRA paricalcitol inhibited aldosterone-induced EGFR transactivation, TGF$\alpha$ /ADAM-17 gene upregulation, and downstream mechanisms, including proinflammatory factors overexpression. In conclusion, our data suggest that the anti-inflammatory actions of paricalcitol in tubular cells could depend on the inhibition of TGF$\alpha /$ ADAM17/EGFR pathway in response to aldosterone, showing an important mechanism of VDRAs action.

\section{Introduction}

One of the earliest pathologic features of chronic kidney disease (CKD) patients is active vitamin $\mathrm{D}$ deficiency $[1$, 2]. Increasing data show that vitamin $\mathrm{D}$ receptor agonists (VDRAs) therapy decreases proteinuria, may reduce renal damage progression, and improves cardiovascular outcomes in CKD patients [1-3]. These beneficial effects are independent of serum parathyroid hormone, phosphorus, and calcium levels suggesting that vitamin D presents pleotropic actions, beyond mineral metabolism regulation $[1,4]$. Active vitamin D (1,25-dihydroxy vitamin $\mathrm{D}(3)$ or calcitriol) mediates its biological effects by binding to the vitamin $\mathrm{D}$ receptor (VDR), which then translocates to the nuclei of target cells [1]. In experimental renal disease vitamin D or VDRAs treatment diminished fibrosis, mesangial proliferation, podocyte loss, and inflammatory cell infiltration [5-10]. However, the molecular mechanism 


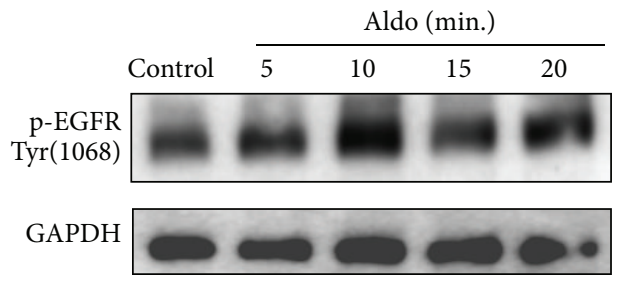

(a)

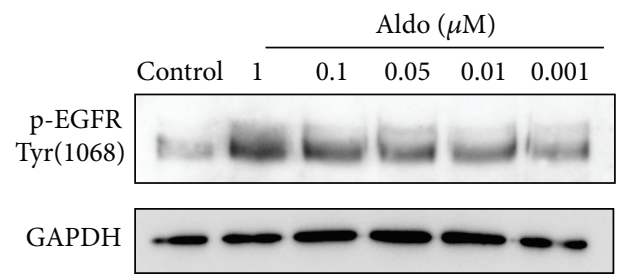

(b)

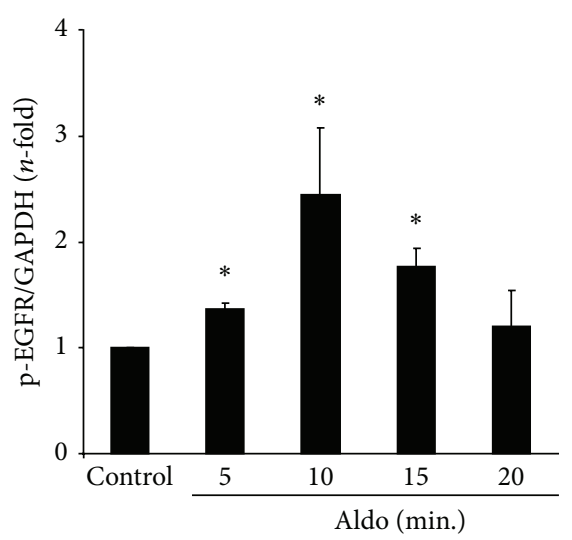

(c)

FIGURE 1: Aldosterone induces EGFR phosphorylation in cultured tubular epithelial cells. Human tubular epithelial cells were treated (a) with $1 \mu \mathrm{mol} / \mathrm{L}$ aldosterone (Aldo) for increasing times or (b) with several concentrations (range $1-0.001 \mu \mathrm{mol} / \mathrm{L}$ Aldo) for $15 \mathrm{~min}$. (c) The figure shows a quantification of time-course EGRF phosphorylation. The data are expressed as mean \pm SEM of 4 independent experiments. ${ }^{*} P<0.05$ versus control.

involved in the anti-inflammatory effects of vitamin $\mathrm{D}$ in the setting of CKD remains poorly characterized.

The renin-angiotensin-aldosterone system (RAAS) is a major mediator of progressive renal injury in $\mathrm{CKD}$, with angiotensin II (AngII) and aldosterone (Aldo) being the most relevant RAAS components [11, 12]. Both factors promote renal inflammation, fibrosis, and podocyte injury [13-15]. There is a close relation between vitamin D and the RAAS. The hormonal form of vitamin $\mathrm{D}$ is a negative endocrine regulator of the RAAS by suppressing renin biosynthesis [16]. Homozygous VDR knockout mice develop high renin hypertension, cardiac hypertrophy, and increased susceptible to kidney damage following unilateral ureteral obstruction $[17,18]$. Therefore, investigation of underlying mechanisms implicated in the relation between RAAS and vitamin D actions in CKD is an important field of research.

Emerging evidence suggests that blockade of epidermal growth factor receptor (EGFR) can be a therapeutic option for renal diseases. Experimental studies have shown that genetic or pharmacological EGFR blockade ameliorates renal disease progression, mainly by diminishing kidney fibrosis $[19,20]$. Regarding the RAAS, both AngII and Aldo, after binding to their specific receptors, can transactivate EGFR, via "a disintegrin and metalloproteases" (ADAMs), thus regulating cellular functions, including proliferation, hypertrophy, and migration [21-23]. ADAMs are membranespanning metalloproteases involved in cleavage of extracellular substrates (shedding), including EGF family ligands, both constitutively and in response to regulatory stimulation [24, 25]. In the kidney, ADAM17, also known as TACE, participates in the shedding of the EGFR ligands, heparin binding EGF-like growth factor (HB-EGF), and transforming growth factor- $\alpha$ (TGF- $\alpha$ ) [26-29]. Both ligands are involved in AngII-induced EGFR transactivation, although some differences have been described between cell types and tissues [30]. In mice, ADAM17-mediated TGF- $\alpha$ shedding contributes to AngII-induced experimental renal fibrosis [20]. Most of the studies on Aldo/EGFR pathway have been done in cultured cells, mainly in vascular smooth muscle cells [14] and in mesangial cells, the latter showing a role in cell proliferation [31]. We now demonstrated here that, in cultured tubular epithelial cells, Aldo activates the EGFR pathway via ADAM-17/TGF- $\alpha$ shedding, leading to upregulation of proinflammatory factors. These data are in line with our recent observation that blockade of the ADAM17/EGFR axis prevents experimental renal inflammation induced by systemic administration of the TWEAK cytokine [32], showing that this pathway, besides regulating proliferation and fibrosis, could contribute to renal inflammation. Furthermore, we now show that the beneficial antiinflammatory effects of VDRAs such as paricalcitol in renal disease may be explained by inhibition of Aldo-mediated proinflammatory factors overexpression through modulation of ADAM17/TGF- $\alpha /$ EGFR signalling axis and dampening of downstream mechanisms, including ERK and STAT-1 activation. Our data add novel information about mechanisms involved in the well-known anti-inflammatory properties of 


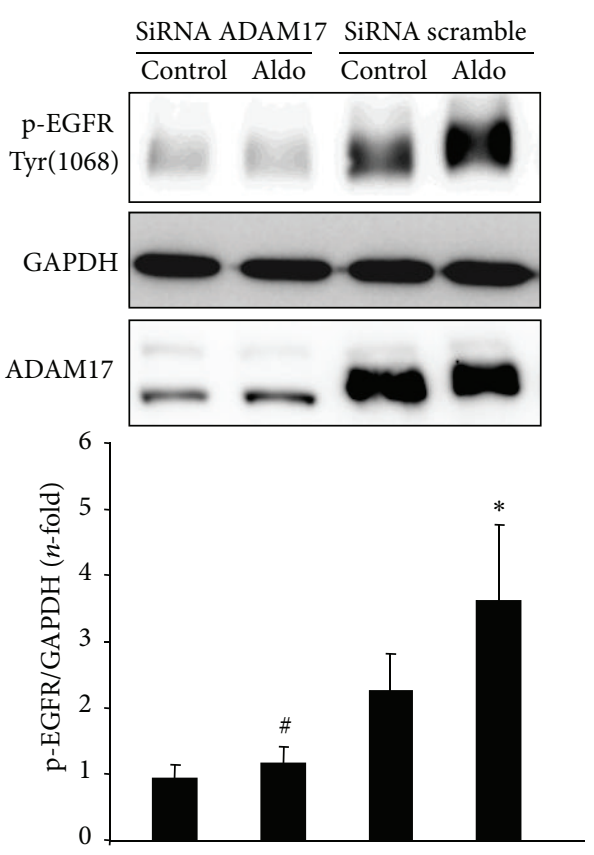

(a)

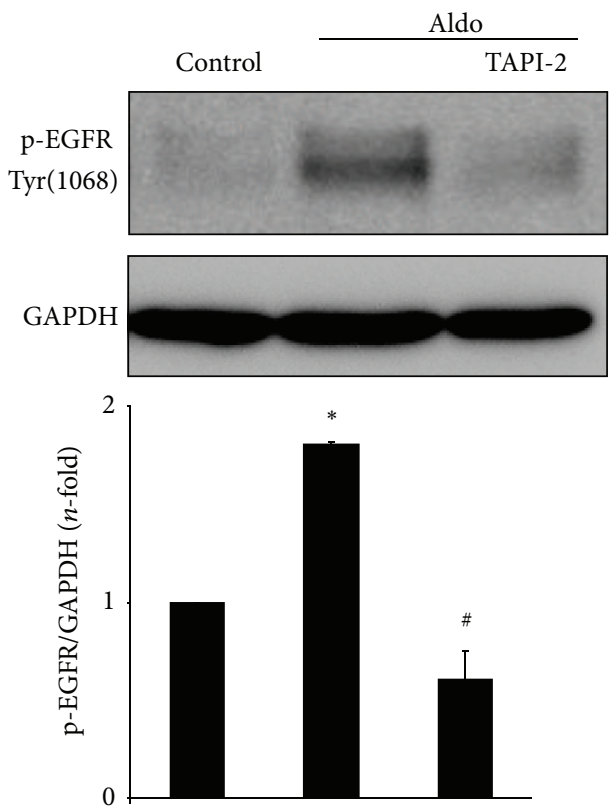

(b)

FIGURE 2: ADAM17 inhibition blocks aldosterone-mediated EGFR activation in tubular epithelial cells. HK2 cells were transfected with an ADAM17 siRNA or scrambled siRNA, as described in "methods," before stimulation with $1 \mu \mathrm{mol} / \mathrm{L}$ Aldo for 15 min. Phosphorylated-EGFR levels were evaluated by Western blot using an antibody against Y1068 phosphorylated-EGFR (p-EGFR1068). GAPDH levels were used as loading control and ADAM17 as silencing control. (a) Representative Western blot and quantification of data expressed as mean \pm SEM of 4 independent experiments. ${ }^{*} P<0.05$ versus untreated siRNA control-transfected cells control. ${ }^{\#} P<0.05$ versus Aldo-treated siRNA scramble cells. (b) Cells were preincubated with the specific ADAM17 inhibitor TAPI-2 $(50 \mu \mathrm{mol} / \mathrm{L})$ for 1 hour and then stimulated with $1 \mu \mathrm{mol} / \mathrm{L}$ Aldo for 15 min. Representative Western blot and data expressed as mean \pm SEM of 4 independent experiments. ${ }^{*} P<0.05$ versus control. ${ }^{\#} P<0.05$ versus Aldo.

VDRAs and contribute to better design of future clinical trials.

\section{Material and Methods}

2.1. Cultured Cells. Human kidney proximal tubule epithelial cells (HK2 cell line, ATCC CRL-2190) were grown in RPMI 1640 with $10 \%$ fetal bovine serum (FBS), $1 \%$ glutamine, $100 \mathrm{U} / \mathrm{mL}$ penicillin, $100 \mu \mathrm{g} / \mathrm{mL}$ streptomycin, $5 \mu \mathrm{g} / \mathrm{mL}$ insulin-transferrin-selenite, and $36 \mathrm{ng} / \mathrm{mL}$ hydrocortisone in $5 \% \mathrm{CO}_{2}$ at $37^{\circ} \mathrm{C}$. When cells reached 60 to $70 \%$ confluence, they were incubated in serum-free medium for 24 hours before the experiments.

Tubuloepithelial proximal murine cells (MCT cell line) were originally obtained from Dr. Eric Neilson (Vanderbilt University) and used for gene expression studies. These cells were grown in RPMI 1640 with 10\% FBS, 1\% glutamine, $100 \mathrm{U} / \mathrm{mL}$ penicillin, and $100 \mu \mathrm{g} / \mathrm{mL}$ streptomycin in $5 \% \mathrm{CO}_{2}$ at $37^{\circ} \mathrm{C}$. When reached 60 to $70 \%$ confluence, they were maintained in RPMI with 1\% FBS for 24 hours.

Cells were treated with recombinant Aldo $(1 \mu \mathrm{mol} / \mathrm{L}$; Sigma). In some experiments cells were preincubated for 1 hour with the following inhibitors prior to stimulation: the EGFR kinase inhibitor AG1478 (100 nmol/L), the ERK inhibitor U0126 (10 $\mu \mathrm{mol} / \mathrm{L}$; Calbiochem), TAPI-2, a specific inhibitor of ADAM-17 (50 $\mu \mathrm{mol} / \mathrm{L}$, Enzo Life Sciences), and a specific inhibitor of HB-EGF, CRM197 (10 $\mu \mathrm{g} / \mathrm{mL}$, Sigma). In some experiments, cells were preincubated for 24 hours with a neutralizing antibody anti-TGF- $\alpha(2.5 \mu \mathrm{g} / \mathrm{mL}, \mathrm{Abcam})$ and for 48 hours with paricalcitol $(12 \mu \mathrm{mol} / \mathrm{L}$, Abbott). DMSO was used as a solvent in many of these reagents but had no effect on cell viability or on gene expression levels (data not shown).

2.2. Protein Studies. The EGFR phosphorylation status was analysed by Western blotting. Briefly, proteins were obtained using lysis buffer [ $50 \mathrm{mmol} / \mathrm{L}$ Tris- $\mathrm{HCl}$ and $150 \mathrm{~mol} / \mathrm{L} \mathrm{NaCl}$; $2 \mathrm{mmol} / \mathrm{L}$ EDTA, $2 \mathrm{mmol} / \mathrm{L}$ EGTA, and $0.2 \%$ Triton X$100,0.3 \%$ IGEPAL; $10 \mu \mathrm{L} / \mathrm{mL}$ protease inhibitor cocktail; $10 \mu \mathrm{L} / \mathrm{mL}$ PMSF and $10 \mu \mathrm{L} / \mathrm{mL}$ orthovanadate]. Protein content was quantified by the BCA method, using bovine serum albumin (BSA) as standard. Cell lysates $(25 \mu \mathrm{g} /$ lane) were separated on $6 \%$ to $12 \%$ SDS-polyacrylamide gels under reducing conditions. Samples were transferred to nitrocellulose membranes (Bio-Rad), blocked in $50 \mathrm{mmol} / \mathrm{L}$ Tris$\mathrm{HCl}, \mathrm{pH} 7.5,150 \mathrm{mmol} / \mathrm{L} \mathrm{NaCl}, 0.05 \%$ Tween-20, and 5\% milk, and incubated overnight at $4^{\circ} \mathrm{C}$ with the following antibodies [dilution]: anti-phosphorylated-EGFR on Tyrosine (Y) 1068 (p-EGFR ${ }_{1068}$ ) [1:250] (Calbiochem), ADAM17 [1:1000] (Abcam), EGFR [1:250], p-ERK1/2 [1:200] (Santa Cruz Biotechnology), and p-STAT1 [1:500] (Invitrogen). 


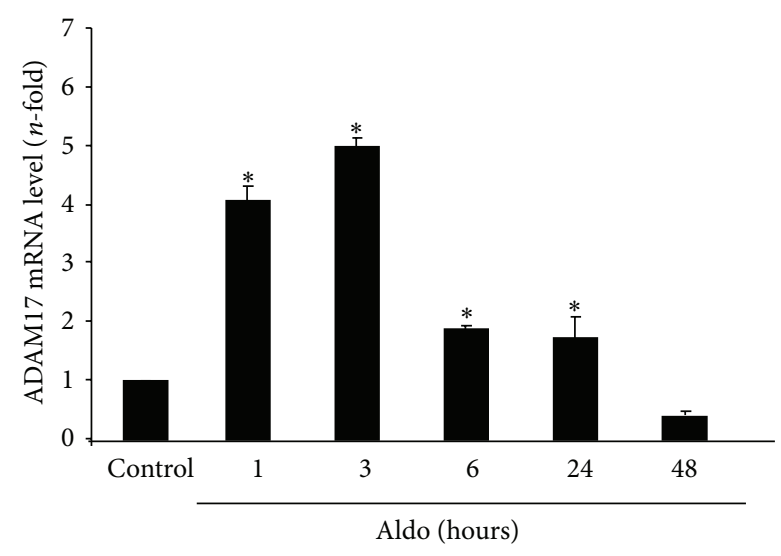

(a)

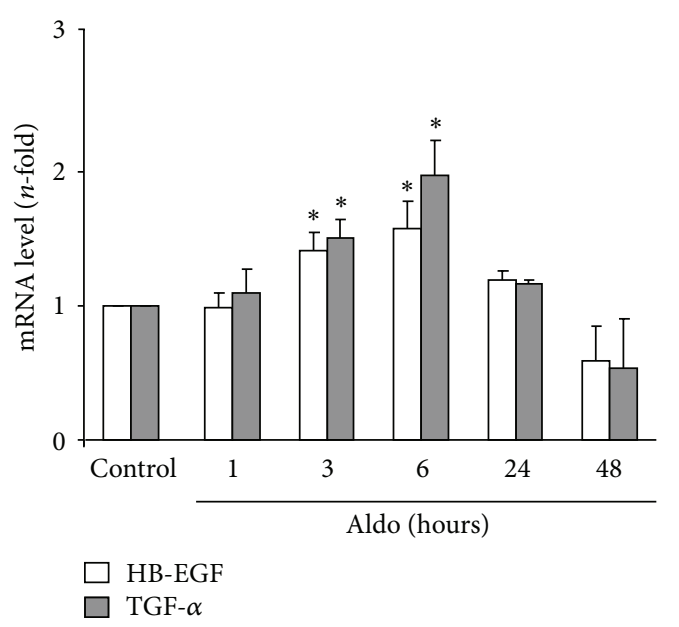

(b)

FIGURE 3: Aldosterone regulates genes expression of ADAM17 (a), TGF- $\alpha$, and HB-EGF (b). Cells were treated with $1 \mu$ mol/L Aldo for increasing times and gene expression levels were evaluated by real-time PCR. Data are expressed as mean \pm SEM of 3 independent experiments. ${ }^{*} P<0.05$ versus control.
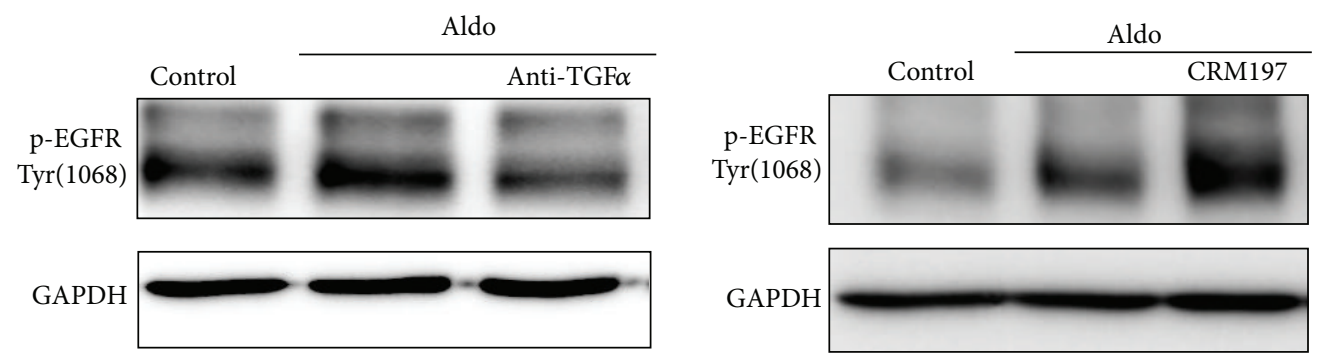

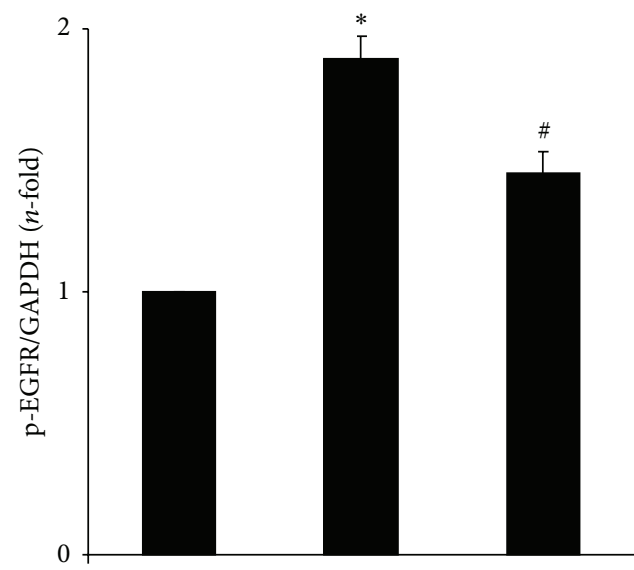

(a)

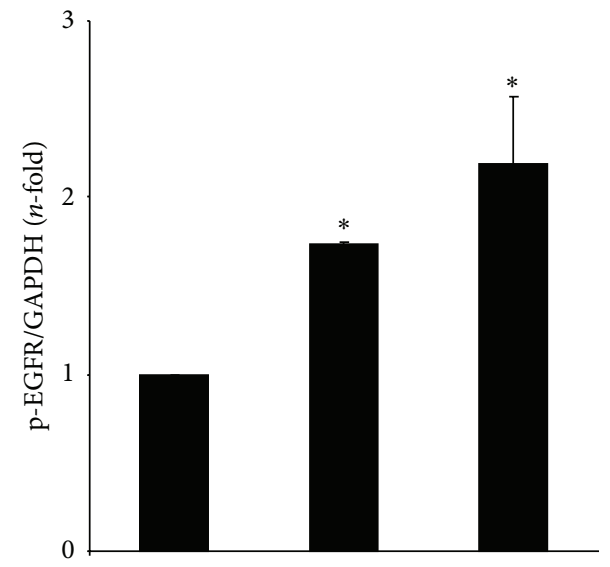

(b)

FIgURE 4: Aldosterone transactivates EGFR via TGF $\alpha$, but not HB-EGF, shedding. Cells were pretreated for $24 \mathrm{~h}$ with a neutralizing antibody against TGF $\alpha(2.5 \mu \mathrm{g} / \mathrm{mL})$ (a) or 1 hour with the HB-EGF pharmacological inhibitor CRM197 $(10 \mu \mathrm{mol} / \mathrm{L})(\mathrm{b})$ before stimulation with $1 \mu \mathrm{mol} / \mathrm{L}$ Aldo for $15 \mathrm{~min}$. Western blot experiment and data are expressed as mean \pm SEM of 3 or 5 independent experiments, respectively. ${ }^{*} P<0.05$ versus control. ${ }^{\#} P<0.05$ versus Aldo.

Subsequently, membranes were incubated with a peroxidaseconjugated secondary antibody and developed using the ECL chemiluminescence kit (Amersham Pharmacia Biotech). Protein quality and transfer efficiency were assessed by Ponceau red staining (not shown). To assess protein loading, membranes were incubated with anti-GAPDH $[1: 10000]$ (Chemicon International). Total proteins were used as control for phosphorylation studies. Films were scanned using the Gel Doc EZ machine imager and analysed using the Image Lab 3.0 (Bio-Rad). 


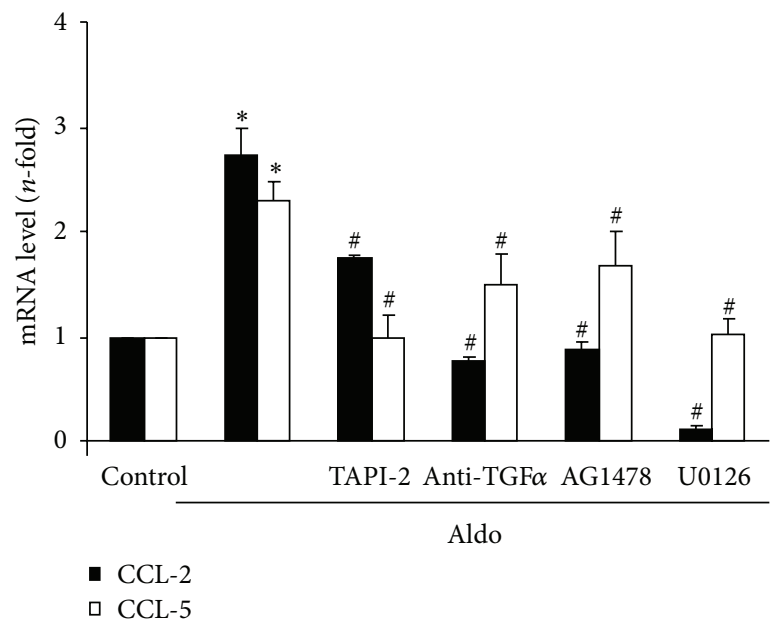

FIGURE 5: ADAM17/TGF- $\alpha /$ EGFR signaling blockade inhibits aldosterone-mediated proinflammatory factors upregulation. Cells were pretreated with the specific ADAM17 inhibitor TAPI-2 $(50 \mu \mathrm{mol} / \mathrm{L} ; 1$ hour), a neutralizing antibody against TGF $\alpha(2.5 \mu \mathrm{g} / \mathrm{mL}, 24 \mathrm{hour})$, the EGFR kinase inhibitor AG 1478 ( $100 \mathrm{nmol} / \mathrm{L}, 1$ hour), or the ERK inhibitor U0126 (10 $\mu \mathrm{mol} / \mathrm{L} ; 1$ hour) before stimulation with $1 \mu \mathrm{mol} / \mathrm{L}$ Aldo for 6 hours. CCL-2 and CCL-5 gene expression levels were determined by real-time PCR. Data are expressed as mean \pm SEM of 2-3 experiments. ${ }^{*} P<0.05$ versus control. ${ }^{\#} P<0.05$ versus Aldo.

2.3. Gene Silencing. The ADAM-17 gene was silenced using an interference silencer siRNA or its corresponding scramble control (Ambion). Subconfluent cells were transfected for 24 hours with $25 \mathrm{nmol} / \mathrm{L}$ siRNA using $50 \mathrm{nmol} / \mathrm{L}$ of Lipofectamine RNAiMAX (Invitrogen), according to the manufacturer's instructions. Subsequently, cells were incubated with $10 \%$ FBS heat inactivated for 24 hours. Then, cells were incubated in serum-free medium for 24 hours before the experiment. The specificity and efficiency of silencing were checked by Western blot with an anti-ADAM-17 antibody (AbCam) [1:1000].

2.4. Gene Expression Studies. Total RNA was isolated in Trizol (Invitrogen, Groningen, Netherlands) from samples and mouse kidney cells. cDNA was synthesized using the High Capacity cDNA Archive Kit (Applied Biosystems, Foster City, CA) using $2 \mu \mathrm{g}$ of total RNA with random hexamer primers, following the manufacturer's instructions. We performed real-time PCR expression using probes (Taqman probes labelled with FAM fluorophore) from Applied Biosystems: VDR Mm_00437297_ml; ADAM17 Mm_00456428_ml; CCL-2 Mm00441242_ml; CCL-5 Mm_01302428_ml; $\quad$ TGF- $\alpha$ Mm_00446232_ml. Data were normalized to $18 \mathrm{~S}$ ribosomal RNA of eukaryotic: 4210893E (VIC). The number of copies of mRNA for each sample was calculated by the instrument software using the Ct. value (shaped point arithmetic analysis on the thermocycler). The results were expressed in relative copy number calculated relative to unstimulated cells or control mice, after normalization to $18 \mathrm{~S}$.

2.5. Statistical Analysis. The results shown in the text are expressed as mean \pm SEM. The differences between the groups treated with agonists and controls were evaluated by the Student's $t$-test and Mann-Whitney test, and $P<0.05$ was considered significant. Statistical analysis was performed using SPSS statistical software (version 11.0, Chicago, IL).

\section{Results}

3.1. Aldosterone Induces EGFR Transactivation via ADAM17 and Subsequent Release of TGF- $\alpha$ in Cultured Tubular Epithelial Cells. Aldo induced EGFR transactivation in several cells, including epithelial cells and mesangial cells [31, 33]. In cultured human tubular epithelial cells (HK2 cell line), Aldo induced a rapid activation of EGFR, as shown by increased EGFR phosphorylation on Tyr1068, in a time and dosedependent manner, presenting a maximal effect at $1 \mu \mathrm{mol} / \mathrm{L}$ Aldo after 10 min (Figures 1(a), 1(b) and 1(c)). The blockade of ADAM17, by gene silencing or pharmacological inhibition using TAPI-2, markedly diminished Aldo-induced EGFR phosphorylation (Figures 2(a) and 2(b)).

ADAM17 mRNA is constitutively expressed in normal adult human kidneys and is increased in disease conditions [34]. In cultured tubular epithelial cells stimulation with Aldo rapidly increased ADAM17 gene expression, which remained elevated up to 24 hours (Figure 3(a)). Among the EGFR ligands, HB-EGF and TGF- $\alpha$ are released by ADAM17 and have a role in renal diseases. In tubular epithelial cells, Aldo upregulated gene expression of HB-EGF and TGF- $\alpha$, observed after 3 hours (Figure 3(b)).

TGF- $\alpha$ blockade, using a specific neutralizing antibody, inhibited EGFR phosphorylation in response to Aldo in tubular cells (Figure 4(a)). In contrast, the pharmacological inhibition of HB-EGF by CRM197, a nontoxic mutant of diphtheria toxin that neutralizes HB-EGF binding to EGFR [29], had no effect on Aldo-mediated EGFR activation (Figure 4(b)).

3.2. Aldosterone Regulates Proinflammatory Gene Expression via the ADAM-17/TGF- $\alpha / E G F R$ Axis in Cultured Tubular Epithelial Cells. Aldo exerts proinflammatory actions in the 


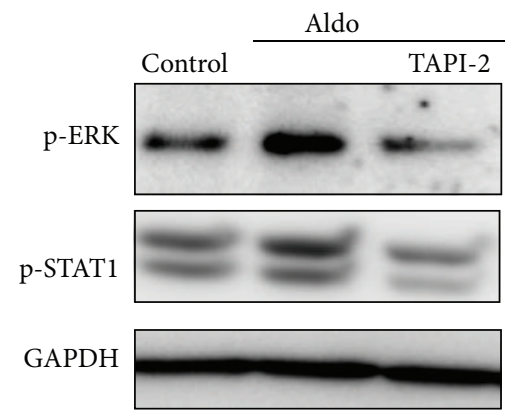

(a)

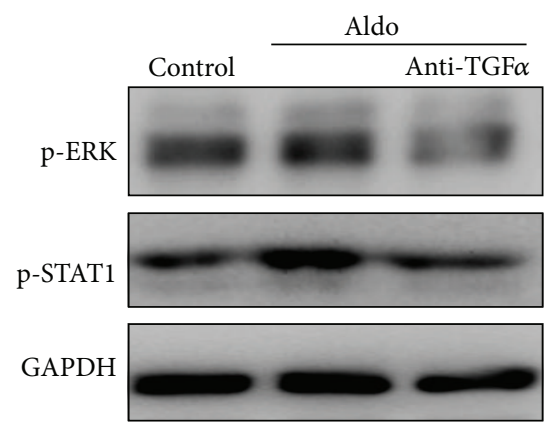

(b)

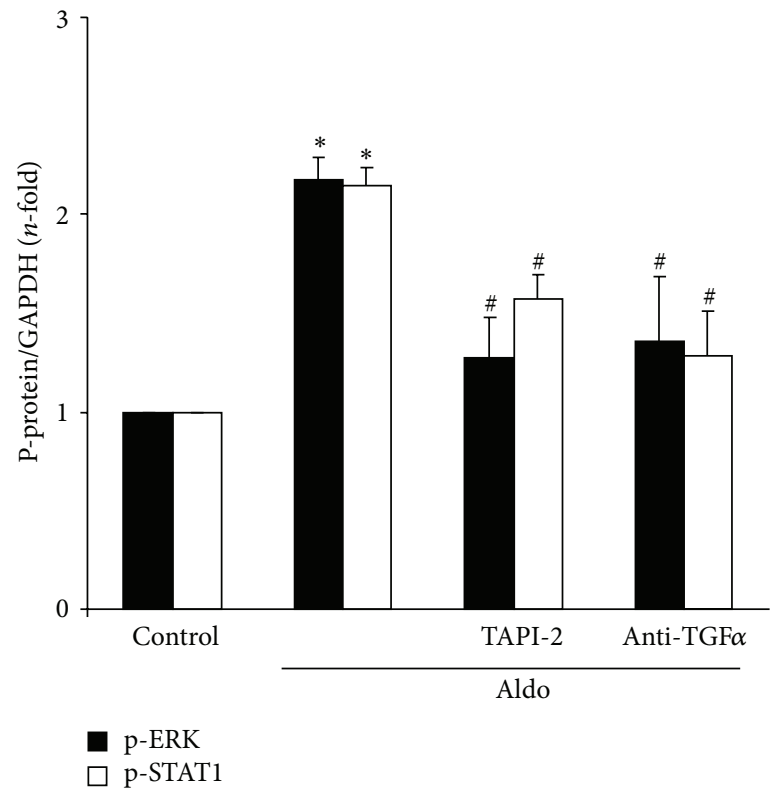

(c)

FIGURE 6: Aldosterone activates ERK and STAT pathways via ADAM-17/TGF- $\alpha$ /EGFR axis. HK2 cells were preincubated with (a) the specific ADAM17 inhibitor TAPI-2 (50 $\mu \mathrm{mol} / \mathrm{L}$; 1 hour $)$ or (b) a neutralizing antibody against TGF $\alpha(2.5 \mu \mathrm{g} / \mathrm{mL}, 24$ hour $)$ and then stimulated with $1 \mu \mathrm{mol} / \mathrm{L}$ Aldo for $15 \mathrm{~min}$. Figures (a) and (b) show representative Western blot experiment and (c) data expressed as mean \pm SEM of 3 experiments. ${ }^{*} P<0.05$ versus control. ${ }^{\#} P<0.05$ versus Aldo.

kidney, including the regulation of proinflammatory gene expression in cultured cells [35]; however, the role of the ADAM-17/EGFR pathway in these Aldo-mediated responses has not been evaluated. In cultured tubular epithelial cells, we have blocked ADAM-17/TGF- $\alpha$ /EGFR pathway using the following inhibitors: the ADAM17 inhibitor TAPI-2, an antiTGF- $\alpha$ neutralizing antibody, and the EGFR kinase inhibitor AG1478. All of these inhibitors significantly diminished Aldo-induced gene upregulation of the proinflammatory factors CCL-2 and CCL-5 (Figure 5).

\subsection{Aldosterone Activates Several Intracellular Mechanisms} via the ADAM-17/TGF- $\alpha / E G F R$ Axis. Among the EGFR downstream signalling mechanisms, activation of the MAPK cascade has special relevance in the regulation of inflammatory events. Aldo increased EGFR phosphorylation on tyrosine 1068, which has been previously involved in ERK signalling [29, 34]. In human tubular cells, Aldo increased ERK phosphorylation and ERK blockade diminished Aldoinduced proinflammatory gene overexpression (Figure 5).
Moreover, ERK activation was prevented when the ADAM$17 /$ TGF- $\alpha$ /EGFR pathway was inhibited using the abovedescribed specific blockers (Figures 6(a), 6(b) and 6(c)). Aldo also activated STAT-1 via the ADAM-17/TGF- $\alpha /$ EGFR pathway (Figures 6(a), 6(b) and 6(c)).

\subsection{Paricalcitol Inhibits Aldosterone-Induced Proinflamma-} tory Gene Expression in Cultured Renal Cells by Modulating the ADAM-17/TGF- $\alpha / E G F R$ Axis. In tubular epithelial cells, preincubation with the VDRA paricalcitol for 48 hours, inhibited proinflammatory genes induction caused by Aldo (Figure 7). These data confirm the anti-inflammatory properties of paricalcitol.

Paricalcitol blocked Aldo-induced EGFR transactivation, as shown by the downregulation of phosphorylated-EGFR levels (Figures 8(a) and 8(b)) and ADAM-17/TGF- $\alpha$ gene overexpression (Figure 8(c)) to control values.

During renal damage, VDR expression is downregulated $[1,3]$. Interestingly, in tubular epithelial cells Aldo downregulated VDR gene and protein levels (Figures $8(a), 8(d)$, 


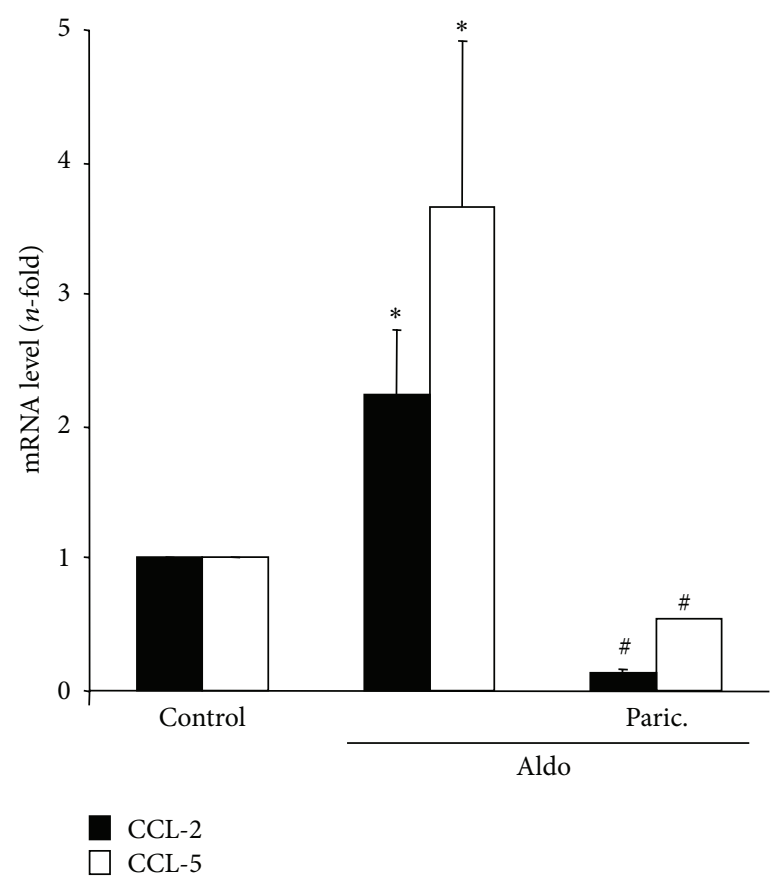

FIGURE 7: Paricalcitol inhibits aldosterone-induced proinflammatory genes in cultured tubular epithelial cells. Cells were pretreated with the analogue of vitamin D paricalcitol $(12 \mu \mathrm{mol} / \mathrm{L})$ for 48 hours before stimulation with $1 \mu \mathrm{mol} / \mathrm{L}$ Aldo for 6 hours. Gene expression levels were determined by real-time PCR. Data are expressed as mean \pm SEM of 3 independent experiments. ${ }^{*} P<0.05$ versus control. ${ }^{\#} P<0.05$ versus Aldo.

and $8(\mathrm{e}))$. Pretreatment with paricalcitol restored VDR levels, indicating that beneficial effects of paricalcitol could be due to modulation of VDR.

Finally, paricalcitol also blocked ERK and STAT-1 activation in response to Aldo stimulation (Figure 9).

\section{Discussion}

Chronic inflammation is a main feature of CKD. Among the factors involved in the inflammatory response in the kidney, local activation of RAAS has special relevance. AngII, the main effector peptide of this system, has been extensively demonstrated to promote renal inflammation [11]. There is previous evidence that Aldo also contributes to this process. Multiple experimental studies in models of hypertension, renal damage, and heart failure have demonstrated that selective Aldo blockade by eplerenone attenuates tissue injury in part by reducing inflammation in Aldo target organs $[13,15$, 35]. Treatment with an aldosterone synthase inhibitor ameliorated experimental diabetic nephropathy by decreasing renal inflammation, matrix formation, and albuminuria [36]. Data presented here demonstrate that the ADAM-17/TGF$\alpha /$ EGFR axis is an important mechanism involved in the regulation of proinflammatory factors by Aldo in cultured tubular epithelial cells (Figure 10(a)). Other data also support the involvement of the EGFR/ADAM17 axis in inflammation $[37,38]$, as we have recently described in TWEAK-mediated experimental renal inflammation [32]. In addition, targeting ADAM17 by pharmacologic inhibition or gene knockout attenuates the inflammatory response in animal models of vascular damage, including hypertension, atherosclerosis, and pulmonary vascular inflammation [21, 38-40].

EGFR transactivation is regulated by ligand sheddase activity [41]. Thus far, 12 EGFR ligands have been described, among them TGF- $\alpha$, HB-EGF, amphiregulin, and connective tissue growth factor could be relevant in renal pathology [4143]. Regarding the kidney, EGF modulates glomerular hemodynamics and renal metabolism, while TGF- $\alpha$, HB-EGF, and amphiregulin participate in cell survival/proliferation $[41,43]$. Moreover, TGF- $\alpha$ has been involved in genetic susceptibility to renal disease [44] and in AngII-mediated experimental renal fibrosis [20]. HB-EGF contributes to cell regeneration and repair after ischemia [41]. In HB-EGFdeficient mice with progressive glomerulonephritis, inflammatory renal infiltration and albuminuria were lower which was ascribed to EGFR pathway inhibition in podocytes [45]. In cultured tubular cells, we have found that Aldo upregulates both EGFR ligands, TGF- $\alpha$ and HB-EGF, but only TGF$\alpha$ mediates Aldo-induced EGFR transactivation, at least at the time point evaluated. This illustrates that EGFR ligands involved in transactivation are cell and stimuli specific and indicates that future studies are needed to evaluate the EGFR ligands involved in Aldo actions in the kidney. In human renal and cardiovascular pathophysiology, ADAM17 expression may be increased $[21,34,46]$. Our findings suggest that Aldo is one of the drivers of increased ADAM17 expression in tubular cells. Moreover, ADAM17 SNPs have been associated to increases in cardiovascular mortality [47].

Activation of the RAAS has been associated to activation of EGFR signalling in renal and cardiovascular diseases. AngII via EGFR pathway regulates hypertrophy 


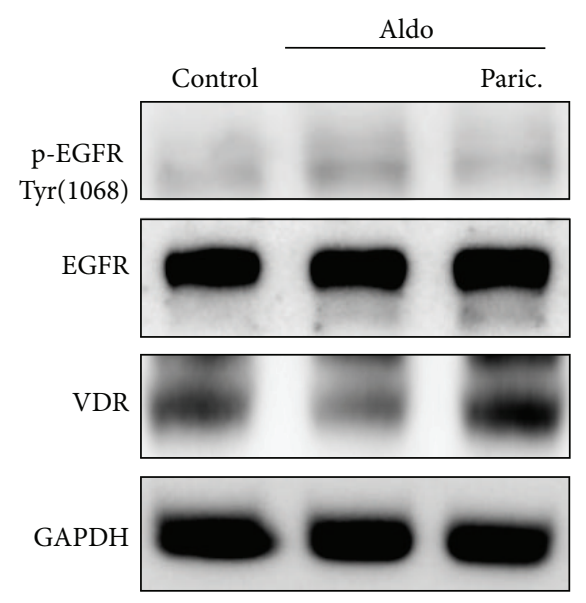

(a)

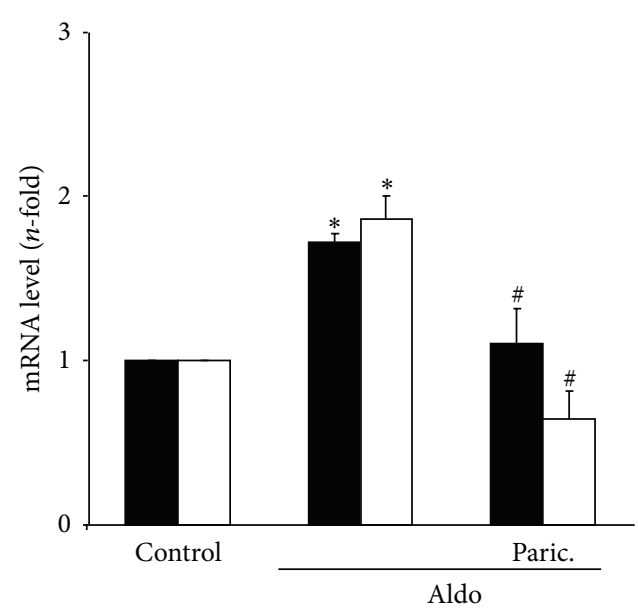

(c)

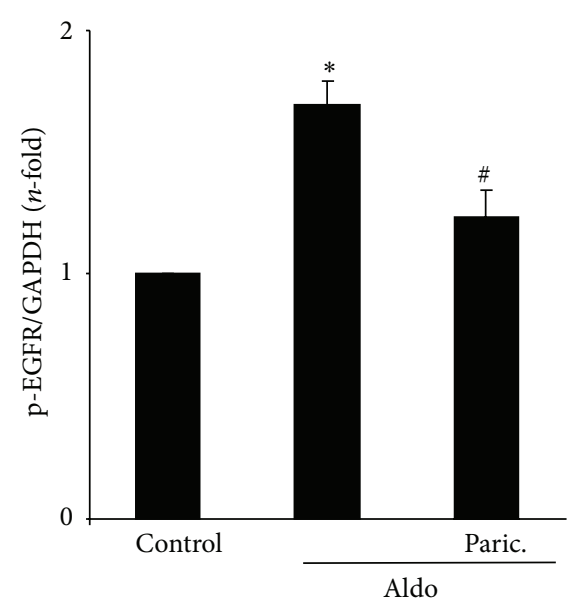

(b)

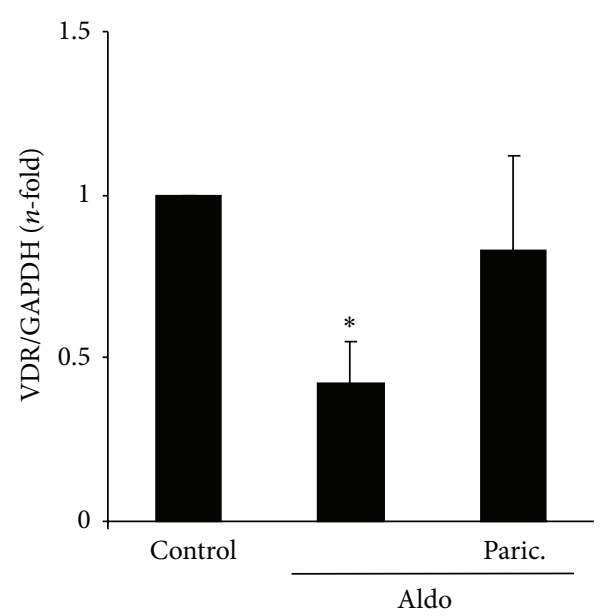

(d)

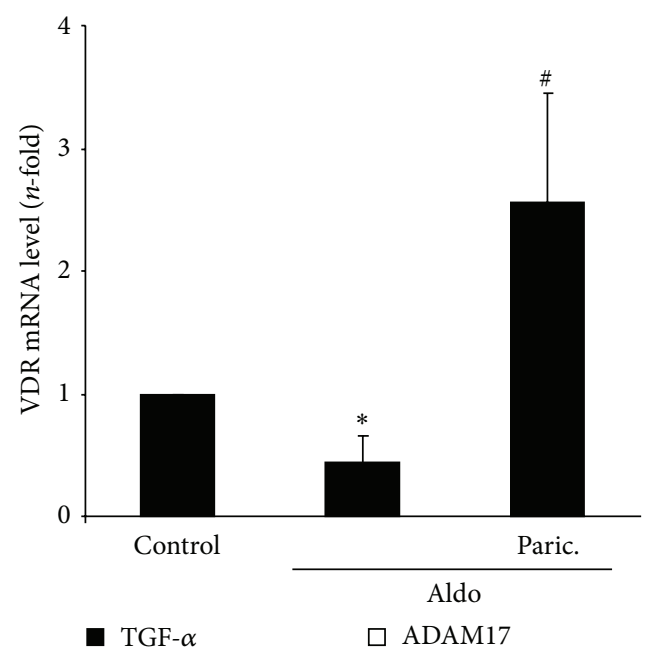

(e)

FIGURE 8: Paricalcitol inhibits aldosterone-induced activation of ADAM-17/TGF- $\alpha$ /EGFR signalling pathway. Cells were pretreated with the analogue of vitamin D Paricalcitol $(12 \mu \mathrm{mol} / \mathrm{L}$ ) for 48 hours before stimulation with $1 \mu \mathrm{mol} / \mathrm{L}$ Aldo for 15 min (protein) or 6 hours (gene studies). Paricalcitol inhibits Aldo-induced EGFR activation (a,b) and gene overexpression of TGF $\alpha$ and HB-EGF (c). Figure (a) shows a representative Western blot, in (b) quantification of p-EGFR and in (c) gene expression levels by real-time PCR. Paricalcitol restores Aldoinduced changes in VDR protein (a,d) and gene (e) expression levels. Figure (a) shows a representative Western blot, in (d) quantification of VDR protein levels and in (e) gene expression levels. Data are expressed as mean \pm SEM of 3 independent experiments. ${ }^{*} P<0.05$ versus control. ${ }^{\#} P<0.05$ versus Aldo. 


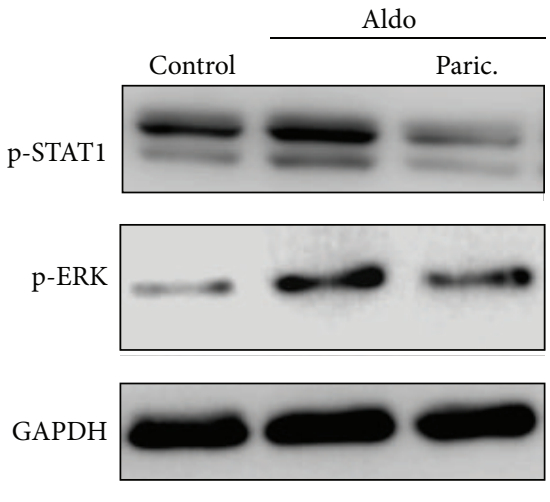

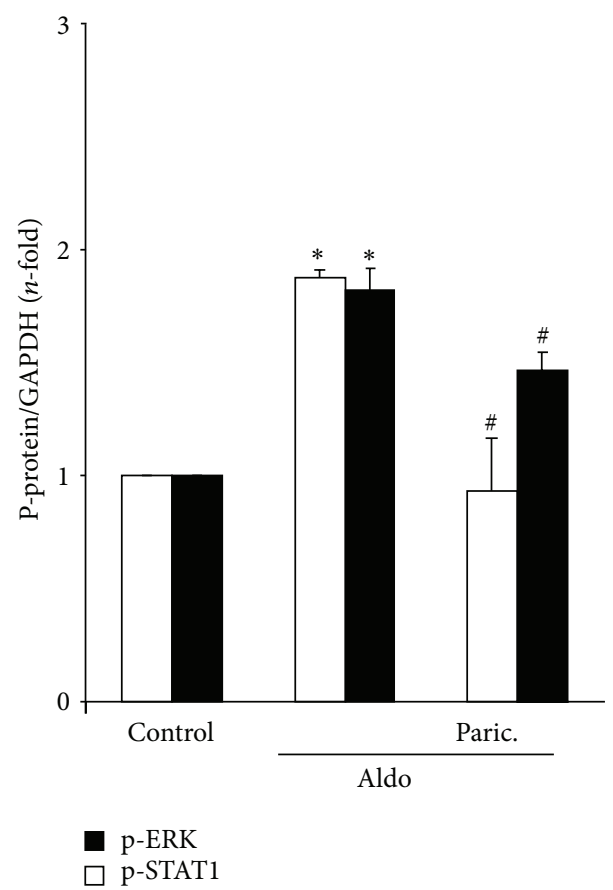

(b)

FIGURE 9: Paricalcitol inhibits aldosterone-mediated activation of ERK and STAT-1 pathway. HK2 cells were preincubated with paricalcitol $(12 \mu \mathrm{mol} / \mathrm{L})$ for 48 hours before stimulation with $1 \mu \mathrm{mol} / \mathrm{L}$ Aldo for $15 \mathrm{~min}$. Figure (a) shows a representative experiment and in (b) quantification of $\mathrm{p}$-ERK and $\mathrm{p}$-STAT1 expressed as mean \pm SEM of 3 independent experiments. ${ }^{*} P<0.05$ versus control. ${ }^{\#} P<0.05$ versus Aldo.

and fibrosis in the kidney [20]. In porcine renal proximal tubular cells HB-EGF shedding-dependent EGFR transactivation regulates AngII-induced cell hypertrophy [48]. Interestingly, Smad activation, the main pathway controlling fibrosis, is independent of HB-EG/EGFR pathway [48]. In mesangial cells, Aldo activates EGFR linked to ROS production, ERK signalling, and modulating cell growth [31], as described in myocytes [49] and vascular cells [50]. In other cell types, Aldo/EGFR may signal through PI3kinase/Akt/mTOR/p70S6 K1 [22]. We have described here that, in tubular cells, Aldo activates ADAM17 leading to rapid and significant activation of EGFR, which in turn activates downstream cascades, such as the MAPK ERK kinase and the STAT-1 transcription factor (Figure 10(a)).

Several lines of evidence have suggested a potential antiinflammatory activity of vitamin $\mathrm{D}$ in $\mathrm{CKD}[6,19]$. In experimental glomerular diseases and obstructive nephropathy, administration of vitamin $\mathrm{D}$ reduces inflammatory cell infiltration $[6-9,20]$. Vitamin D and VDRAs may exert their immunomodulatory actions by direct modulation of immune cells, including macrophages, dendritic cells, and $\mathrm{T}$ cells [51]. Vitamin D modulates dendritic cells' maturation and function, the population and function of FOXP3+ and IL10 -producing $\mathrm{T}$ regulatory cells [52], and regulates Thl7 differentiation and decreasses IL-17A production [53]. Besides regulating immune cells, VDRAs could also exert antiinflammatory actions by modulating responses of resident renal cells. In this sense, we have found that, in tubular epithelial cells, paricalcitol inhibits Aldo-induced proinflammatory genes upregulation. The mechanisms involved in these antiinflammatory effects of vitamin D in epithelial cells are not well known. In monocytes/macrophages, vitamin D inhibits LPS-induced cytokine production by upregulating MAPK phosphatase-1 that inactivates p38 and JNK [54]. In tubular cells, we found that paricalcitol inhibited Aldo-induced activation of ERK and STAT-1 (Figure 10(b)), identifying a novel mechanisms of action of VDRAs.

Earlier studies showed a relation between vitamin D and EGFR signalling pathways. Those studies were focused on EGFR binding and regulation of its gene expression [55-58]. After that, many studies demonstrated that vitamin D or VDRAs increase cell proliferation via EGFR in different cell types, by a mechanism that includes changes in EGFR membrane trafficking and downregulation of EGFR growth signalling $[1,59]$. However, recent studies suggest that this antiproliferative effect could be mediated by the modulation of the TGF- $\alpha$ /EGFR autocrine growth loop [60]. Our results show that in cultured tubular epithelial cells, the VDRA agonist paricalcitol inhibited the EGFR pathway activated by Aldo by modulating TGF- $\alpha$ /ADAM17/EGFR signalling pathway activation and expression, supporting this hypothesis.

\section{Conclusions}

Our in vitro data in tubular cells stimulated with Aldo suggest that the anti-inflammatory properties of the VDRA paricalcitol are, at least in part, mediated by inhibition 


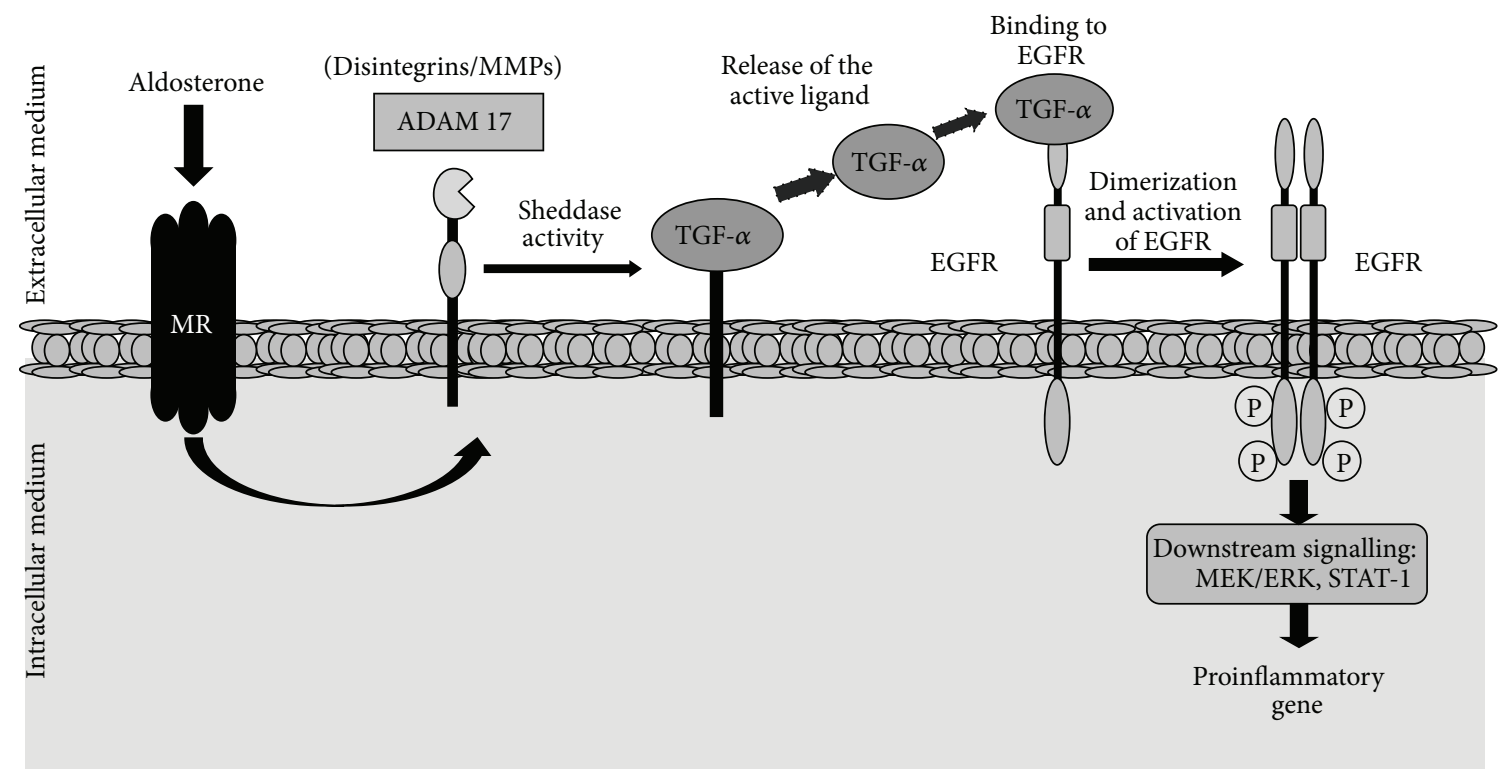

(a)

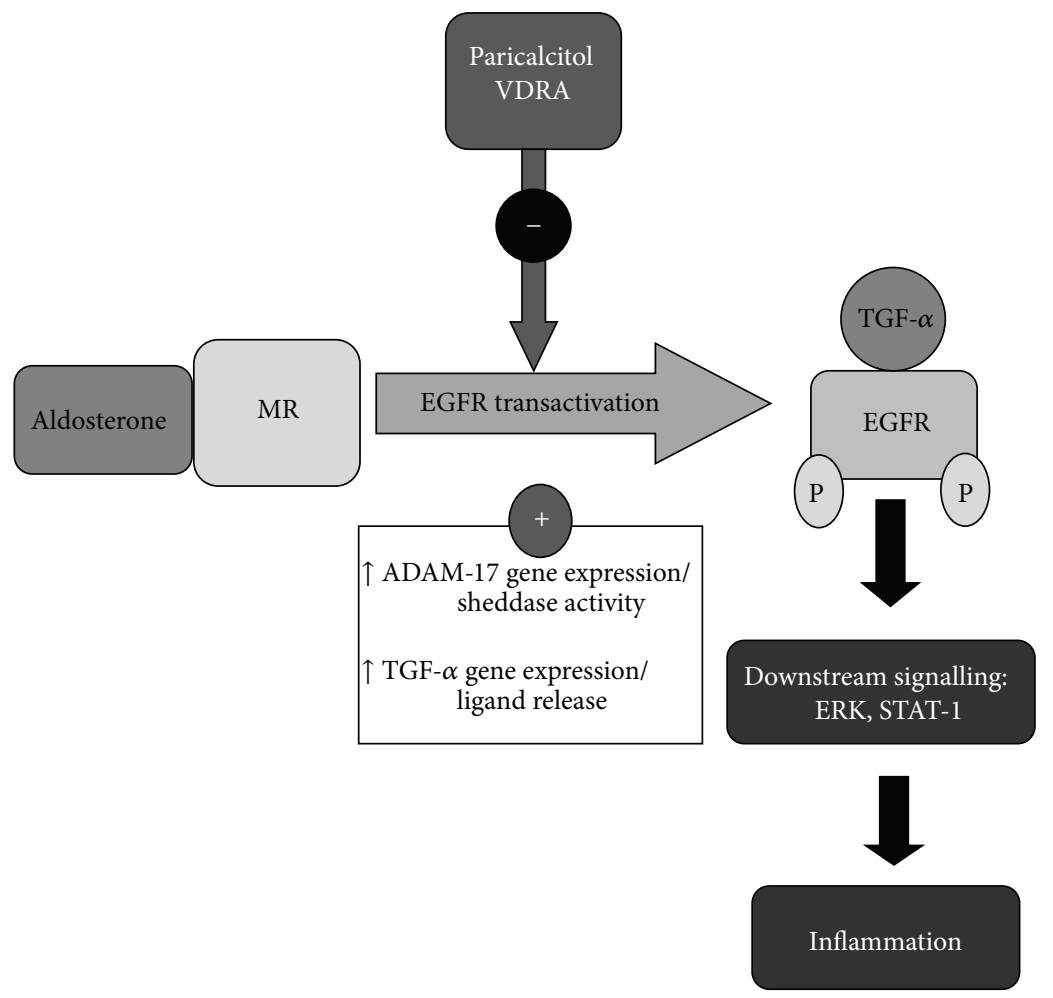

(b)

FIGURE 10: Aldosterone-induced inflammatory responses: role of the ADAM-17/TGF- $\alpha$ /EGFR axis and modulation by paricalcitol. (a) Aldosterone activates the ADAM-17/TGF- $\alpha$ /EGFR axis to regulate proinflammatory factors. (b) Paricalcitol inhibits aldosterone-induced activation of ADAM-17/TGF- $\alpha /$ EGFR signalling pathway. MR: mineralocorticoid receptor; VDRA: vitamin D receptor activators.

of the ADAM-17/TGF- $\alpha / E G F R$ and downstream signals, including ERK and STAT-1. In renal diseases, local activation of RAAS contributes to inflammation and tissue damage. Thus, our results show a novel signalling pathway that could be involved in the observed anti-inflammatory effects of paricalcitol in CKD and expand the current understanding of the mechanisms involved in the renoprotective effects of vitamin $\mathrm{D}$ and its analogs. 


\section{Conflict of Interests}

The authors declare that there is no conflict of interests regarding the publication of this paper.

\section{Acknowledgments}

This work was supported by grants from the Instituto de Salud Carlos III (ISCIIIRETIC REDINREN RD12, PI11/ 01854, PI041/00041, PI13/00047, PIE13/00051, and PI0/ 00072), Comunidad de Madrid (Fibroteam S2010/BMD-232; CIFRA S2010/BMD-2378), Sociedad Española de Nefrología, European Network (FP7-HEALTH-2013-INNOVATION-1602422), and Programa Intensificación Actividad Investigadora (ISCIII/Agencia Laín-Entralgo/CM) to Alberto Ortiz.

\section{References}

[1] J. M. Valdivielso, J. Cannata-Andía, B. Coll, and E. Fernández, "A new role for vitamin D receptor activation in chronic kidney disease," The American Journal of Physiology —Renal Physiology, vol. 297, no. 6, pp. F1502-F1509, 2009.

[2] A. Levin, G. L. Bakris, M. Molitch et al., "Prevalence of abnormal serum vitamin $\mathrm{D}, \mathrm{PTH}$, calcium, and phosphorus in patients with chronic kidney disease: results of the study to evaluate early kidney disease," Kidney International, vol. 71, no. 1, pp. 31-38, 2007.

[3] M. V. Pérez-Gómez, A. Ortiz-Arduán, and V. Lorenzo-Sellares, "Vitamin D and proteinuria: a critical review of molecular bases and clinical experience," Nefrologia, vol. 33, no. 5, pp. 716-726, 2013.

[4] E. Gonzalez-Parra, J. Rojas-Rivera, J. Tuñón, M. Praga, A. Ortiz, and J. Egido, "Vitamin D receptor activation and cardiovascular disease," Nephrology Dialysis Transplantation, vol. 27, supplement 4, pp. iv17-iv21, 2012.

[5] N. Bodyak, J. C. Ayus, S. Achinger et al., "Activated vitamin $\mathrm{D}$ attenuates left ventricular abnormalities induced by dietary sodium in Dahl salt-sensitive animals," Proceedings of the National Academy of Sciences of the United States of America, vol. 104, no. 43, pp. 16810-16815, 2007.

[6] M. Mizobuchi, J. Morrissey, J. L. Finch et al., "Combination therapy with an angiotensin-converting enzyme inhibitor and a vitamin $\mathrm{D}$ analog suppresses the progression of renal insufficiency in uremic rats," Journal of the American Society of Nephrology, vol. 18, no. 6, pp. 1796-1806, 2007.

[7] A. Kuhlmann, C. S. Haas, M.-L. Gross et al., "1,25-Dihydroxyvitamin D3 decreases podocyte loss and podocyte hypertrophy in the subtotally nephrectomized rat," The American Journal of Physiology-Renal Physiology, vol. 286, no. 3, pp. F526-F533, 2004.

[8] V. Panichi, M. Migliori, D. Taccola et al., "Effects of 1,25(OH $)_{2} \mathrm{D}_{3}$ in experimental mesangial proliferative nephritis in rats," Kidney International, vol. 60, no. 1, pp. 87-95, 2001.

[9] X. Tan, Y. Li, and Y. Liu, "Paricalcitol attenuates renal interstitial fibrosis in obstructive nephropathy," Journal of the American Society of Nephrology, vol. 17, no. 12, pp. 3382-3393, 2006.

[10] M. Hirata, K. Makibayashi, K. Katsumata et al., "22-Oxacalcitriol prevents progressive glomerulosclerosis without adversely affecting calcium and phosphorus metabolism in subtotally nephrectomized rats," Nephrology Dialysis Transplantation, vol. 17, no. 12, pp. 2132-2137, 2002.

[11] M. Ruiz-Ortega, V. Esteban, M. Rupérez et al., "Renal and vascular hypertension-induced inflammation: role of angiotensin II," Current Opinion in Nephrology and Hypertension, vol. 15, no. 2, pp. 159-166, 2006.

[12] W. Thomas, R. Dooley, and B. J. Harvey, "Aldosterone as a renal growth factor," Steroids, vol. 75, no. 8-9, pp. 550-554, 2010.

[13] A. M. Marney and N. J. Brown, "Aldosterone and end-organ damage," Clinical Science, vol. 113, no. 5-6, pp. 267-278, 2007.

[14] M. Briet and E. L. Schiffrin, "Vascular actions of aldosterone," Journal of Vascular Research, vol. 50, no. 2, pp. 89-99, 2013.

[15] G. Remuzzi, D. Cattaneo, and N. Perico, "The aggravating mechanisms of aldosterone on kidney fibrosis," Journal of the American Society of Nephrology, vol. 19, no. 8, pp. 1459-1462, 2008.

[16] M. H. de Borst, M. G. Vervloet, P. M. ter Wee, and G. Navis, "Cross talk between the renin-angiotensin-aldosterone system and vitamin D-FGF-23-klotho in chronic kidney disease," Journal of the American Society of Nephrology, vol. 22, no. 9, pp. 1603-1609, 2011.

[17] Y. C. Li, J. Kong, M. Wei, Z.-F. Chen, S. Q. Liu, and L.P. Cao, "1,25-Dihydroxyvitamin $\mathrm{D}_{3}$ is a negative endocrine regulator of the renin-angiotensin system," The Journal of Clinical Investigation, vol. 110, no. 2, pp. 229-238, 2002.

[18] M. Xiong, J. Gong, Y. Liu, R. Xiang, and X. Tan, "Loss of vitamin $\mathrm{D}$ receptor in chronic kidney disease: a potential mechanism linking inflammation to epithelial-to-mesenchymal transition," American Journal of Physiology - Renal Physiology, vol. 303, no. 7, pp. F1107-F1115, 2012.

[19] F. Terzi, M. Burtin, M. Hekmati et al., "Targeted expression of a dominant-negative EGF-R in the kidney reduces tubulointerstitial lesions after renal injury," The Journal of Clinical Investigation, vol. 106, no. 2, pp. 225-234, 2000.

[20] A. Lautrette, S. Li, R. Alili et al., "Angiotensin II and EGF receptor cross-talk in chronic kidney diseases: a new therapeutic approach," Nature Medicine, vol. 11, no. 8, pp. 867-874, 2005.

[21] D. Dreymueller, J. Pruessmeyer, E. Groth, and A. Ludwig, "The role of ADAM-mediated shedding in vascular biology," European Journal of Cell Biology, vol. 91, no. 6-7, pp. 472-485, 2012.

[22] H. Ohtsu, P. J. Dempsey, and S. Eguchi, "ADAMs as mediators of EGF receptor transactivation by G protein-coupled receptors," American Journal of Physiology-Cell Physiology, vol. 291, no. 1, pp. C1-C10, 2006.

[23] C. P. Blobel, "ADAMs: key components in egfr signalling and development," Nature Reviews Molecular Cell Biology, vol. 6, no. 1, pp. 32-43, 2005.

[24] S. M. Le Gall, P. Bobé, K. Reiss et al., "ADAMs 10 and 17 represent differentially regulated components of a general shedding machinery for membrane proteins such as transforming growth factor $\alpha$, L-selectin, and tumor necrosis factor $\alpha$, Molecular Biology of the Cell, vol. 20, no. 6, pp. 1785-1794, 2009.

[25] D. Dreymueller, C. Martin, J. Schumacher et al., "Smooth muscle cells relay acute pulmonary inflammation via distinct ADAM17/ErbB axes," The Journal of Immunology, vol. 192, no. 2, pp. 722-731, 2014

[26] J. R. Doedens, R. M. Mahimkar, and R. A. Black, "TACE/ADAM-17 enzymatic activity is increased in response to cellular stimulation," Biochemical and Biophysical Research Communications, vol. 308, no. 2, pp. 331-338, 2003. 
[27] J. M. W. Gee and J. M. Knowlden, "ADAM metalloproteases and EGFR signalling," Breast Cancer Research, vol. 5, no. 5, pp. 223224, 2003.

[28] G. M. Argast, J. S. Campbell, J. T. Brooling, and N. Fausto, "Epidermal growth factor receptor transactivation mediates tumor necrosis factor-induced hepatocyte replication," The Journal of Biological Chemistry, vol. 279, no. 33, pp. 3453034536, 2004.

[29] N. Prenzel, E. Zwick, H. Daub et al., "EGF receptor transactivation by G-protein-coupled receptors requires metalloproteinase cleavage of proHB-EGF," Nature, vol. 402, no. 6764, pp. 884$888,1999$.

[30] S. Higuchi, H. Ohtsu, H. Suzuki, H. Shirai, G. D. Frank, and S. Eguchi, "Angiotensin II signal transduction through the AT1 receptor: novel insights into mechanisms and pathophysiology," Clinical Science, vol. 112, no. 7-8, pp. 417-428, 2007.

[31] S. Huang, A. Zhang, G. Ding, and R. Chen, "Aldosteroneinduced mesangial cell proliferation is mediated by EGF receptor transactivation," American Journal of Physiology-Renal Physiology, vol. 296, no. 6, pp. F1323-F1333, 2009.

[32] S. Rayego-Mateos, J. L. Morgado-Pascual, A. B. Sanz et al., "TWEAK transactivation of the epidermal growth factor receptor mediates renal inflammation," The Journal of Pathology, vol. 231, no. 4, pp. 480-494, 2013.

[33] T. Chiu, C. Santiskulvong, and E. Rozengurt, "EGF receptor transactivation mediates ANG II-stimulated mitogenesis in intestinal epithelial cells through the PI3-kinase/Akt/mTOR/ p70S6K1 signaling pathway," American Journal of PhysiologyGastrointestinal and Liver Physiology, vol. 288, no. 2, pp. G182G194, 2005.

[34] W. B. Melenhorst, L. Visser, A. Timmer, M. C. van den Heuvel, C. A. Stegeman, and H. van Goor, "ADAM17 upregulation in human renal disease: a role in modulating TGF- $\alpha$ availability?" American Journal of Physiology - Renal Physiology, vol. 297, no. 3, pp. F781-F790, 2009.

[35] M. Briet and E. L. Schiffrin, "Aldosterone: effects on the kidney and cardiovascular system," Nature Reviews Nephrology, vol. 6, no. 5, pp. 261-273, 2010.

[36] H. M. Siragy and C. Xue, "Local renal aldosterone production induces inflammation and matrix formation in kidneys of diabetic rats," Experimental Physiology, vol. 93, no. 7, pp. 817824, 2008.

[37] H. Ohtsu, P. J. Dempsey, G. D. Frank et al., "ADAM17 mediates epidermal growth factor receptor transactivation and vascular smooth muscle cell hypertrophy induced by angiotensin II," Arteriosclerosis, Thrombosis, and Vascular Biology, vol. 26, no. 9, pp. e133-e137, 2006.

[38] D. Dreymueller, C. Martin, T. Kogel et al., "Lung endothelial ADAM17 regulates the acute inflammatory response to lipopolysaccharide," EMBO Molecular Medicine, vol. 4, no. 5, pp. 412-423, 2012.

[39] J. Odenbach, X. Wang, S. Cooper et al., "MMP-2 mediates angiotensin ii-induced hypertension under the transcriptional control of MMP-7 and TACE," Hypertension, vol. 57, no. 1, pp. 123-130, 2011.

[40] M. Serino, R. Menghini, L. Fiorentino et al., "Mice heterozygous for tumor necrosis factor- $\alpha$ converting enzyme are protected from obesity-induced insulin resistance and diabetes," Diabetes, vol. 56, no. 10, pp. 2541-2546, 2007.

[41] W. B. W. H. Melenhorst, G. M. Mulder, Q. Xi et al., "Epidermal growth factor receptor signaling in the kidney: key roles in physiology and disease," Hypertension, vol. 52, no. 6, pp. 987993, 2008.

[42] M. Beck Gooz, E. N. Maldonado, Y. Dang et al., "ADAM17 promotes proliferation of collecting duct kidney epithelial cells through ERK activation and increased glycolysis in polycystic kidney disease," The American Journal of Physiology-Renal Physiology, vol. 307, no. 5, pp. F551-F559, 2014.

[43] S. Rayego-Mateos, R. Rodrigues-Díez, J. L. Morgado-Pascual et al., "Connective tissue growth factor is a new ligand of epidermal growth factor receptor," Journal of Molecular Cell Biology, vol. 5, no. 5, pp. 323-335, 2013.

[44] D. Laouari, M. Burtin, A. Phelep et al., "TGF- $\alpha$ mediates genetic susceptibility to chronic kidney disease," Journal of the American Society of Nephrology, vol. 22, no. 2, pp. 327-335, 2011.

[45] G. Bollée, M. Flamant, S. Schordan et al., "Epidermal growth factor receptor promotes glomerular injury and renal failure in rapidly progressive crescentic glomerulonephritis," Nature Medicine, vol. 17, no. 10, pp. 1242-1250, 2011.

[46] T. Obama, T. Takayanagi, T. Kobayashi et al., "Vascular induction of a disintegrin and metalloprotease 17 by angiotensin II through hypoxia inducible factor $1 \alpha$," The American Journal of Hypertension, vol. 28, no. 1, pp. 10-14, 2015.

[47] P. E. Morange, D. A. Tregouet, T. Godefroy et al., "Polymorphisms of the TNF and the TACE/ADAM17 genes in relation to cardiovascular mortality: the AtheroGene study," Journal of Molecular Medicine, vol. 86, no. 10, pp. 1153-1161, 2008.

[48] J. Chen, J.-K. Chen, E. G. Neilson, and R. C. Harris, "Role of EGF receptor activation in angiotensin II-induced renal epithelial cell hypertrophy," Journal of the American Society of Nephrology, vol. 17, no. 6, pp. 1615-1623, 2006.

[49] V. C. De Giusti, M. B. Nolly, A. M. Yeves et al., "Aldosterone stimulates the cardiac $\mathrm{Na}^{+} / \mathrm{H}^{+}$exchanger via transactivation of the epidermal growth factor receptor," Hypertension, vol. 58, no. 5, pp. 912-919, 2011.

[50] K. J. Elliott, A. M. Bourne, T. Takayanagi et al., "ADAM17 silencing by adenovirus encoding miRNA-embedded siRNA revealed essential signal transduction by angiotensin II in vascular smooth muscle cells," Journal of Molecular and Cellular Cardiology, vol. 62, pp. 1-7, 2013.

[51] S. Wu and J. Sun, "Vitamin D, vitamin D receptor, and macroautophagy in inflammation and infection," Discovery Medicine, vol. 11, no. 59, pp. 325-335, 2011.

[52] E. S. Chambers and C. M. Hawrylowicz, "The impact of vitamin $\mathrm{D}$ on regulatory T cells," Current Allergy and Asthma Reports, vol. 11, no. 1, pp. 29-36, 2011.

[53] G. T. González-Mateo, V. Fernández-Míllara, T. Bellón et al., "Paricalcitol reduces peritoneal fibrosis in mice through the activation of regulatory $\mathrm{T}$ cells and reduction in IL-17 production," PLoS ONE, vol. 9, no. 10, Article ID e108477, 2014.

[54] Y. Zhang, D. Y. M. Leung, B. N. Richers et al., "Vitamin $\mathrm{D}$ inhibits monocyte/macrophage proinflammatory cytokine production by targeting MAPK phosphatase-1," The Journal of Immunology, vol. 188, no. 5, pp. 2127-2135, 2012.

[55] P. M. Petkovich, J. L. Wrana, A. E. Grigoriadis, J. N. Heersche, and J. Sodek, "1,25-Dihydroxyvitamin D3 increases epidermal growth factor receptors and transforming growth factor $\beta$-like activity in a bone-derived cell line," The Journal of Biological Chemistry, vol. 262, no. 28, pp. 13424-13428, 1987.

[56] O. Garach-Jehoshua, A. Ravid, U. A. Liberman, and R. Koren, "1,25-Dihydroxyvitamin D3 increases the growth-promoting activity of autocrine epidermal growth factor receptor ligands in keratinocytes," Endocrinology, vol. 140, no. 2, pp. 713-721, 1999. 
[57] W.-M. Tong, H. Hofer, A. Ellinger, M. Peterlik, and H. S. Cross, "Mechanism of antimitogenic action of vitamin D in human colon carcinoma cells: relevance for suppression of epidermal growth factor-stimulated cell growth," Oncology Research, vol. 11, no. 2, pp. 77-84, 1999.

[58] M. Koga, J. A. Eisman, and R. L. Sutherland, "Regulation of epidermal growth factor receptor levels by 1,25-dihydroxyvitamin D3 in human breast cancer cells," Cancer Research, vol. 48, no. 10, pp. 2734-2739, 1988.

[59] E. A. González, S. Disthabanchong, R. Kowalewski, and K. J. Martin, "Mechanisms of the regulation of EGF receptor gene expression by calcitriol and parathyroid hormone in UMR 10601 cells," Kidney International, vol. 61, no. 5, pp. 1627-1634, 2002.

[60] J. B. Cordero, M. Cozzolino, Y. Lu et al., "1,25-Dihydroxyvitamin D down-regulates cell membrane growth- and nuclear growth-promoting signals by the epidermal growth factor receptor," The Journal of Biological Chemistry, vol. 277, no. 41, pp. 38965-38971, 2002. 


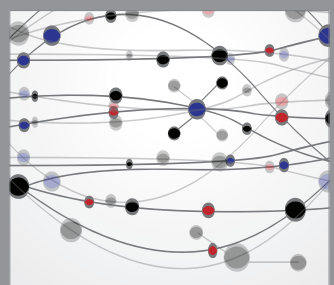

The Scientific World Journal
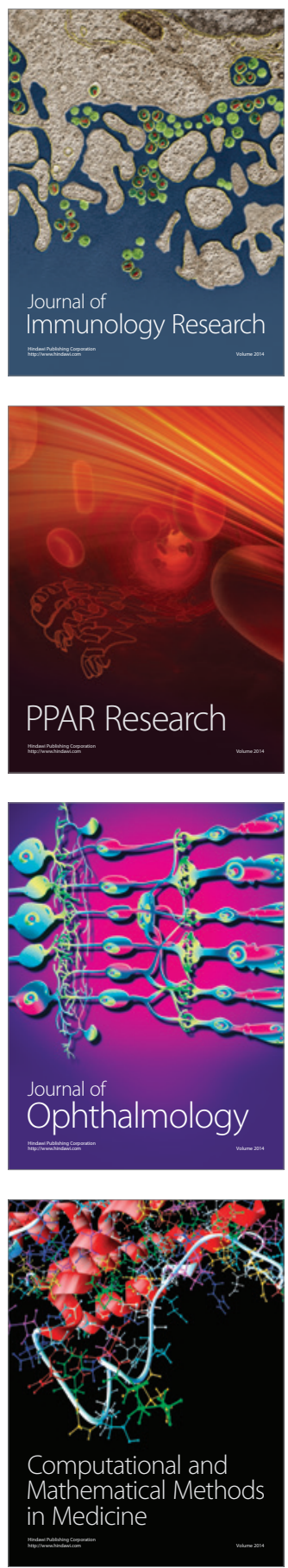

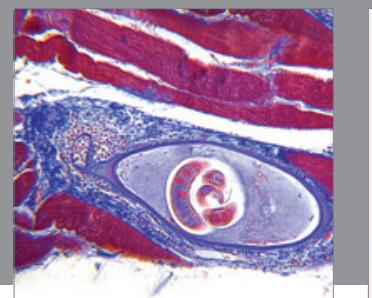

Gastroenterology

Research and Practice
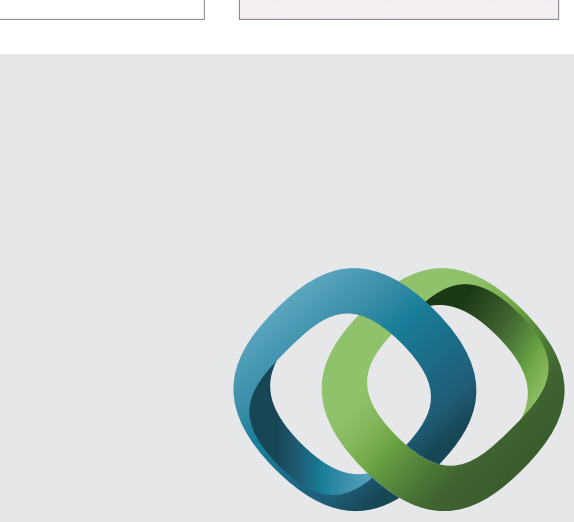

\section{Hindawi}

Submit your manuscripts at

http://www.hindawi.com
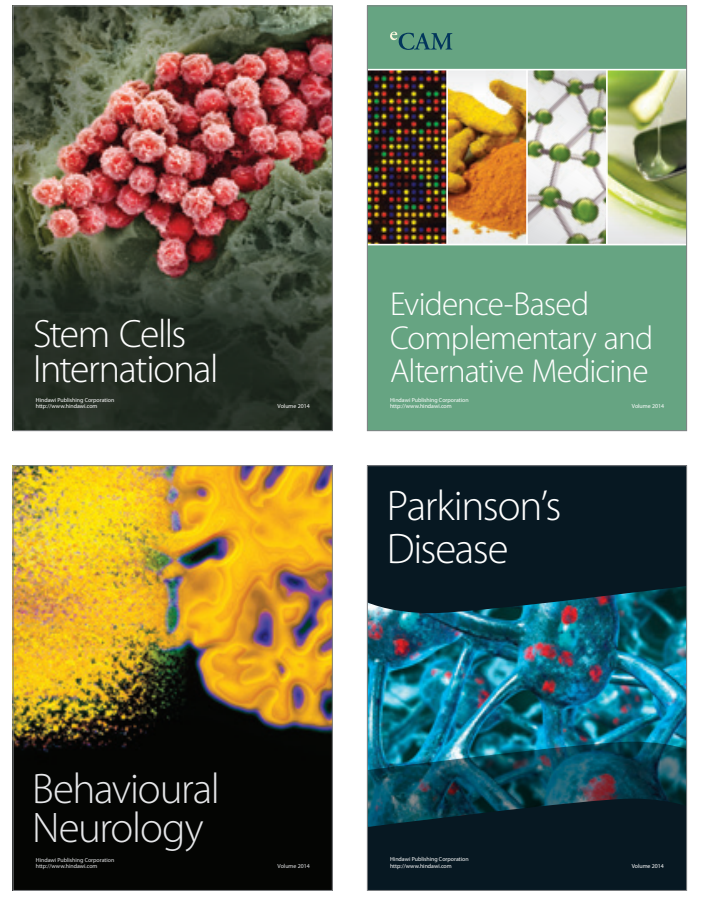
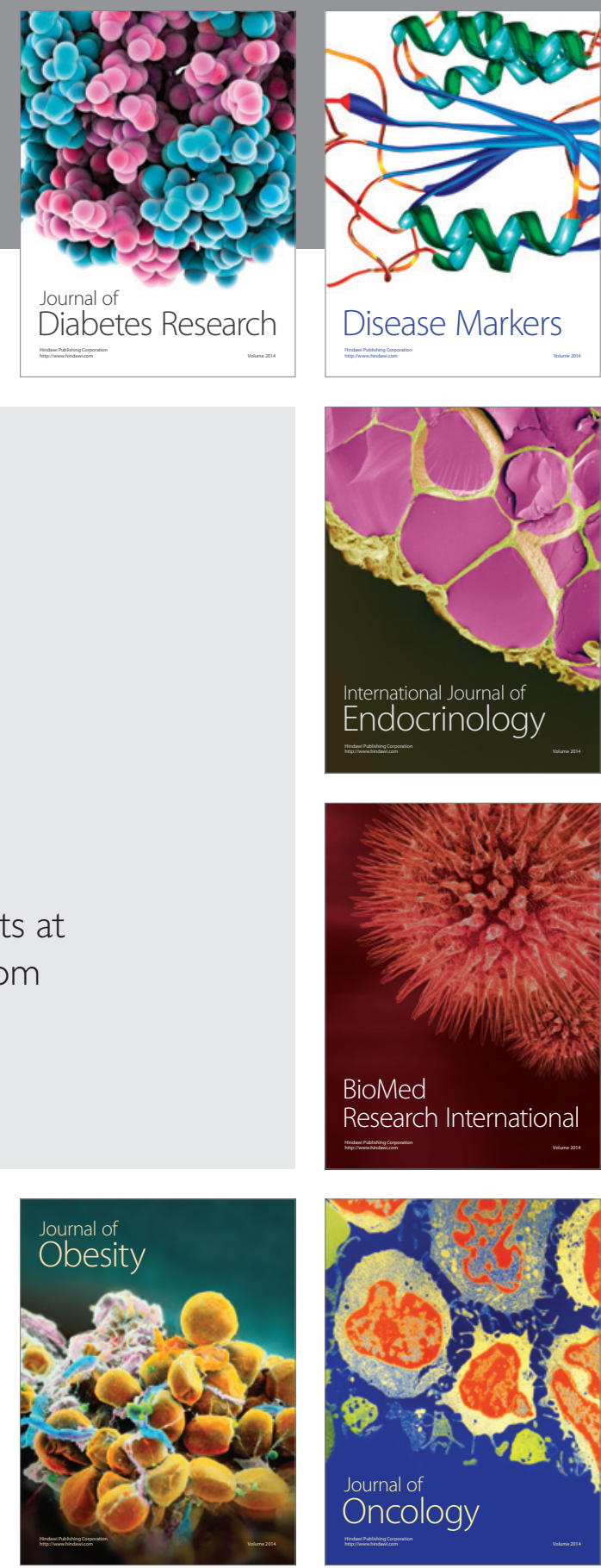

Disease Markers
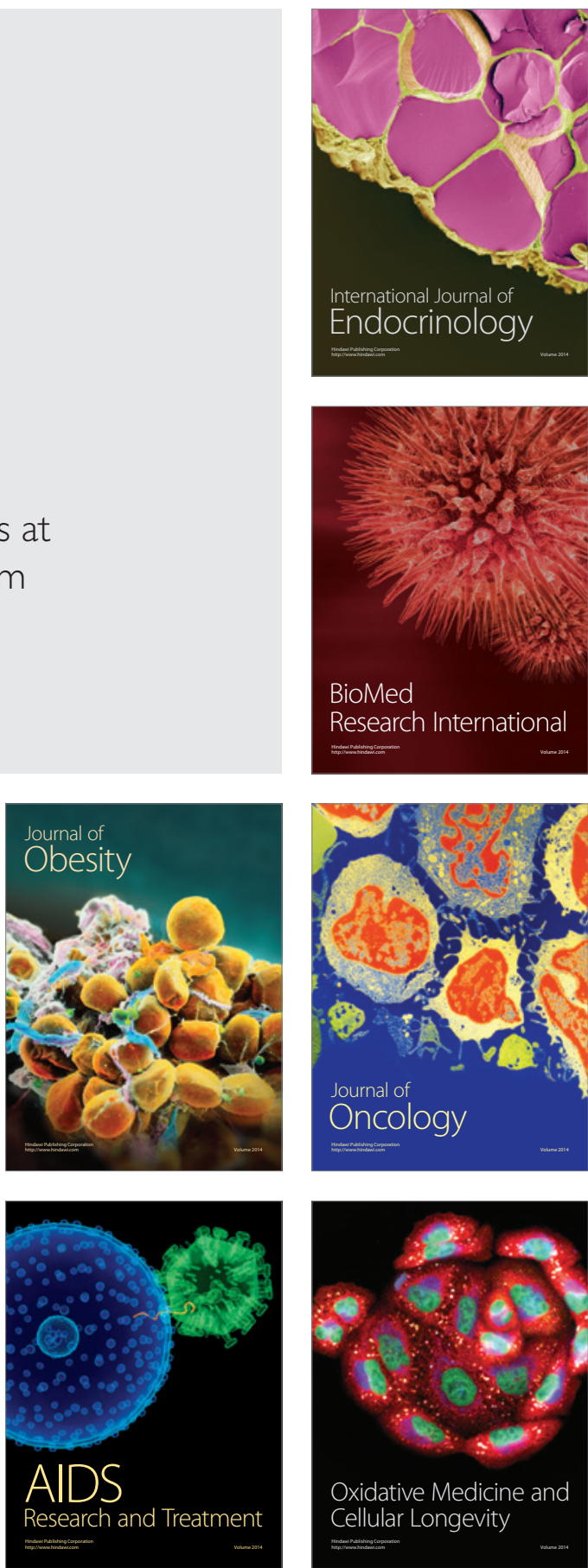